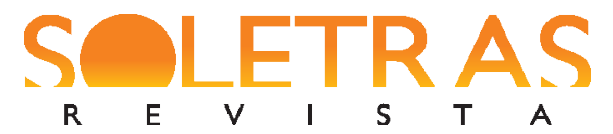

\title{
O Gótico brasileiro na poesia de Carlos Ferreira
}

\author{
Fernando Monteiro de Barros ${ }^{1}$ \\ Márcio Alessandro de Oliveira ${ }^{2}$
}

\begin{abstract}
Resumo: A poesia de Carlos Ferreira (1844-1913), poeta gaúcho, apresenta ocasionais traços do Gótico literário inglês surgido no século XVIII. Os poemas ñA Baronesaò e ñA Escravaò, publicados no livro Redivivas, de 1881, mais do que configurarem um exemplo da presença do Gótico em nossas letras, avultam como textos de fundação do que poderíamos chamar de Gótico brasileiro, no qual, antropofagicamente, elementos convencionais da tradição gótica de outros países são inseridos no cenário geográfico e cultural do Brasil. Os fortes traços de intertextualidade dos poemas com o romance Úrsula (1859), de Maria Firmina dos Reis (1825-1917)ï outro texto fundamental para a categoria em questão ï reforçam esta premissa.
\end{abstract}

Palavras-chave: Gótico brasileiro. Poesia finissecular. Intertextualidade.

\section{Introdução}

Carlos Augusto Ferreira foi um poeta, dramaturgo e jornalista gaúcho, nascido em Porto Alegre em 1844. Na juventude, recebeu de D. Pedro II uma mesada para custear seus estudos na Faculdade de Direito de São Paulo após o monarca, em visita ao Rio Grande do Sul durante a Guerra do Paraguai (1864-1870), ter se impressionado com versos de sua autoria que enalteciam as tropas brasileiras naquela campanha, episódio que narra na crônica ñAs minhas visitas ao Imperadorò (FERREIRA, 1905, p. 111-126). Na faculdade, travou amizade com o poeta Castro Alves(1847-1871). Republicano, Carlos Ferreira abandonou os estudos e passou a se dedicar ao jornalismo, mas até o fim da vida nutriu um sentimento de gratidão e admiração por D. Pedro II, contraditoriamente. Trabalhou no Correio Paulistano, no Diário de Amparo e ajudou a fundar a Gazeta de Campinas, junto a Francisco Quirino dos Santos (1841-1886). Publicou os livros de poesia Cânticos juvenis (1865), Rosas loucas (1871) ï que teve uma segunda edição em 1883 ï, Alcíones (1872), Redivivas (1881) e Plumas ao vento (1908). Publicou também o livro de contos Histórias cambiantes (1874), o

\footnotetext{
${ }^{1}$ Doutor em Letras Vernáculas (Literatura Brasileira), pela UFRJ. Professor Adjunto de Literatura Brasileira do Departamento de Letras da Faculdade de Formação de Professores da UERJ. Professor do Programa de PósGraduação em Letras e Linguística (PPLIN) da UERJ, RJ, RJ, Brasil. E-mail: fernandobarros.letras@ gmail.com

${ }^{2}$ Mestrando em Estudos Literários do Programa de Pós-Graduação em Letras e Linguística (PPLIN) da UERJ, RJ, Brasil. E-mail: marcio-galdino2010@ hotmail.com
} 


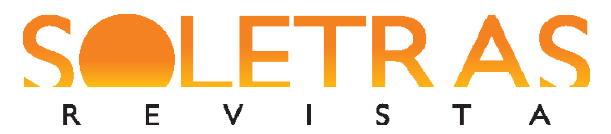

DOSSIÊ ï N. 34 ï 2017.2 İ FERNANDO MONTEIRO DE BARROS MÁRCIO ALESSANDRO DE OLIVEIRA

romance A primeira culpa (1889) e o livro de crônicas Feituras e feições (1905). Carlos Ferreira escreveu várias peças de teatro, tanto dramas como comédias, ñque foram representados, mas de que não se conhece nenhuma publicaçãoò (SPALDING, 1956, p. 201). Faleceu no Rio de Janeiro em 1913. Seus poemas ñA Baronesaò e ñA Escravaò, escritos em 1880 e publicados em Redivivas, põem em cena, diametralmente, dois retratos antitéticos da mulher no Brasil monárquico e escravocrata, nos quais o pano de fundo sociocultural da época reveste-se de nuances goticistas, o que configura um registro precoce e fundador do Gótico brasileiro.

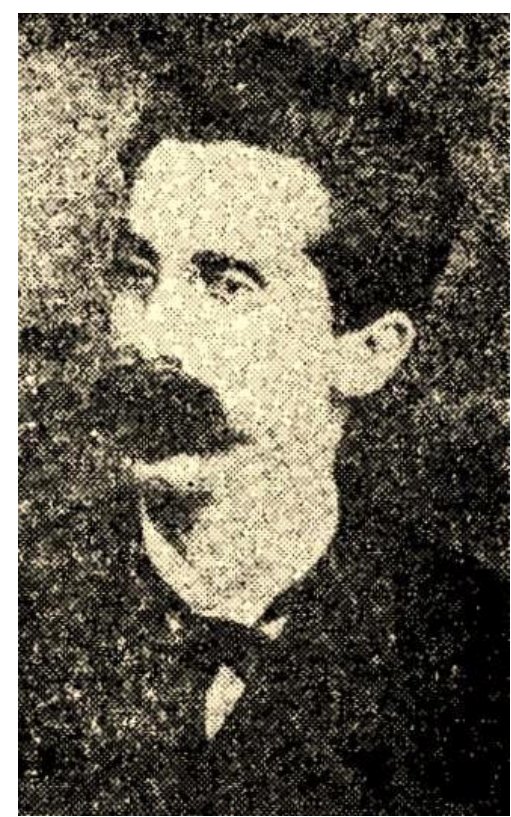

Fig. 1: Carlos Ferreira (1844-1913). ${ }^{3}$

A literatura gótica tem seu início com o romance inglês The castle of Otranto ( $O$ castelo de Otranto), de Horace Walpole (1717-1797), publicado em 1764 e acrescido do subtítulo ña Gothic storyòï uma história gótica ï na segunda edição em 1765. O sucesso do livro ensejou uma série de romances situados em espaços aterrorizantes ligados ao passado pré-moderno, como castelos e mosteiros (que remontavam à Inglaterra católica, anterior a Henrique VIII), e que tinham como protagonistas mais distintivos vilões aristocráticos, mulheres fatais e donzelas indefesas. Porém, mais do que um estilo de época circunscrito à

\footnotetext{
${ }^{3}$ Disponível em: https://commons.wikimedia.org/wiki/File:CarlosAugustoFerreira_poeta.jpg. Acesso: 29 ago. 2017.
} 


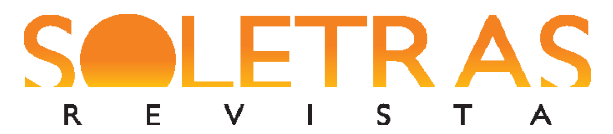

DOSSIÊ ï N. 34 ï 2017.2 İ FERNANDO MONTEIRO DE BARROS MÁRCIO ALESSANDRO DE OLIVEIRA

vigência do Romantismo europeu $і ̈$ do final do século XVIII ao começo do século XIX ï o Gótico acabou por se constituir em um gênero ficcional que tem se desdobrado até os nossos dias, consolidando-se, assim, como uma tradição artística que se espraia para além do romance. Na literatura brasileira, o Gótico foi tradicionalmente ignorado ou desvalorizado pela historiografia literária, entusiasta da tematização da cor local e da nacionalidade (FRANÇA, 2017). Pesquisas recentes, contudo, têm apontado que a presença da tradição gótica em nossas letras é bem maior do que se fazia supor. Há que se ressaltar, todavia, em que consiste o Gótico brasileiro (enquanto subgênero do Gótico, tal como o American Gothic e o Victorian Gothic, por exemplo) e em que medida este se destaca do Gótico no Brasil.

Obras como Noite na taverna (1855) e O Conde Lopo (1886), de Álvares de Azevedo, com seus enredos situados no continente europeu, seriam exemplos do Gótico no Brasil, enquanto obras como o romance Úrsula (1859), de Maria Firmina dos Reis, e o poema ñA Orgia dos Duendesò (1865), de Bernardo Guimarães, pela combinação de elementos convencionais da estética gótica com componentes nativistas, seriam relacionados ao que propomos designar por Gótico brasileiro. É importante ressaltar que o Gótico não pressupõe necessariamente a presença do elemento sobrenatural, que pode estar presente ou não. Nos trópicos americanos ño Gótico se adapta ao contexto político, social e culturalò (EDWARDS; VASCONCELOS, 2016, p. 13), configurando o que alguns críticos denominam por Gótico tropical (SÁ, 2010). Do mesmo modo, o Gótico sulista norte-americano (Southern Gothic) encena enredos góticos no cenário arruinado de regiões como Alabama e Mississippi depois da Guerra de Secessão (1861-1865). De maneira análoga, o Gótico brasileiro pressupõe cenários e aspectos culturais do Brasil como pano de fundo para situações narrativas e personagens identificados com a literatura gótica. Dentro de tal escopo, a casa-grande arruinada dos engenhos e fazendas remanescentes dos tempos da escravidão figura como a versão brasileira dos castelos góticos (BARROS, 2014), conforme romances como A menina morta (1954) de Cornélio Penna e Crônica da casa assassinada (1959) de Lúcio Cardoso logram atestar. Arriscamos afirmar que o Gótico brasileiro, ao incorporar elementos góticos ao cenário local, se constitui dentro do procedimento da antropofagia cultural, tal como apresentado por Oswald de Andrade. 


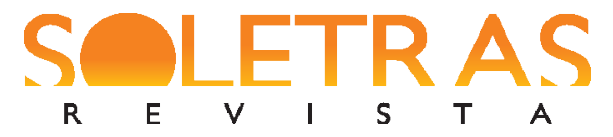

DOSSIÊ ï N. 34 ï 2017.2 Ï FERNANDO MONTEIRO DE BARROS MÁRCIO ALESSANDRO DE OLIVEIRA

\section{Goticismos e intertextualidades na poética finissecular de Carlos Ferreira}

A poesia de Carlos Ferreira apresenta uma forte marca do Romantismo, desde seu livro de estreia, Cânticos juvenis, de 1865, permeado de um lirismo ñexcessivamente dulçuroso e plangenteò (IANNONE, 1974, p. 13), que deixava entrever um eu lírico ñde formação lamartineana, voltado para o amor e a sentimentalidadeò (CUNHA, 1969, p. 213). Rosas loucas, considerado seu melhor livro, publicado em 1871, e republicado em 1883, apresenta, ao lado do ñom hugoanoò e do ñcondoreirismoò ï influência do amigo Castro Alves? Ï um ñfundo macabroò (IANNONE, 1974, p. 13), com fortes inflexões góticas, sobretudo naquele que é, de toda a sua obra, seu poema mais conhecido, que teve enorme popularidade na época, ño Baile das Múmiasò, no qual se descreve um festim dos mortos no cemitério à meia-noite que conta com a presença de fantasmas ilustres como Byron, Goethe e Camões. Até Alcíones (1872) a obra de Ferreira, em que pese os timbres hugoanos e condoreiristas, evidencia também considerável influência de Álvares de Azevedo e Edgar Allan Poe. Este livro apresenta um dos primeiros registros de tradução da poesia de Charles Baudelaire no Brasil (AMARAL, 1996, p. 37), e, sobretudo com os poemas ñO Insoneò, ñUma Cena no Serralhoòe ñA Ideiaò, permite que se franqueie a entrada do poeta gaúcho na confraria dos escritores góticos. Contudo, ao considerarmos a imagética presente nos poemas ñmacabrosò tanto de Rosas loucas quanto de Alcíones, teríamos até esses dois livros apenas um caso de Gótico no Brasil, e não de Gótico brasileiro, que só irá comparecer no livro seguinte.

Redivivas (1881) apresenta em sua maior parte um Romantismo mitigado, em poemas nos quais sobressaem o tom edificante e, vez ou outra, certa nota moralizante. A edição conta com dois prefácios, de Júlio Ribeiro e Francisco Quirino dos Santos, que suspeita nesta nova obra a adesão de Carlos Ferreira à poética do Realismo. Como diz Júlio Ribeiro em um dos prefácios, em forma de carta dirigida ao autor, ñas desgraças da humanidade, a prepotência dos grandes, dos viciosos, o sofrer acrisolado dos pequeninos, dos humildes, eis os teus assuntos prediletosò (RIBEIRO, 1881, p. XxV-Xxvi). Este parece ter sido um dos motivos que fez com que Fausto Cunha demonstrasse pouco entusiasmo por este livro, ao afirmar que, nele, Carlos Ferreira se encontra ñengolfado nessa poesia utilitária, versejando ao Progresso, à Caridade, ao Operário, à Criança, em alexandrinos bemintencionados mas nem por isso de melhor qualidadeò, além de ressaltar que, em seus versos, 


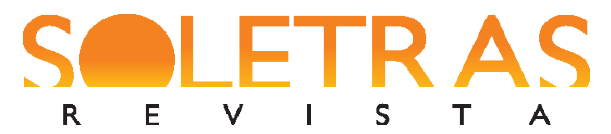

DOSSIÊ ï N. 34 ï 2017.2 İ FERNANDO MONTEIRO DE BARROS MÁRCIO ALESSANDRO DE OLIVEIRA

ña arte saúda a indústriaò, celebrando essa ñalliance monstrueuse de lâart e de lôindustrieò, contra a qual, trinta anos antes, se rebelara Leconte de Lisleò (CUNHA, 1969, p. 212-213).

Redivivas contém, todavia, alguns poucos poemas de lavra decadentista, o que é bem condizente com o ecletismo estilístico da poesia brasileira finissecular. Há um longo poema narrativo, intitulado ñCriançasò, sobre a sedução de meninas adolescentes órfãs, que, apesar do elogio da virtude e da denúncia de injustiça social cometida pelos privilegiados sobre os desvalidos, constrói o personagem do Conde sedutor com fortes traços de dandismo e monstruosidade gótico-byroniana, mas sem apresentar a paisagem e a cultura brasileiras como pano de fundo. Entretanto, ñA Baronesaò e ñA Escravaò são poemas de indiscutível pertencimento ao Gótico brasileiro. É verificável que o tom moralizante e a denúncia de injustiça social permeiem os dois textos, que, lidos em confronto, apresentam o contraste entre luxo perverso e pobreza virtuosa, mote que também enforma ñCriançasò. Mas o goticismo, compreendido como ñaquilo que se aproxima da estética góticaò (COLUCCI; BARROS, 2017, p. 154), se faz perceber nos motivos góticos da aristocracia perversa da mulher fatal e da inocência vitimada da mulher virtuosa.

Jerrold Hogle nos diz que obras artísticas e literárias podem por vezes variar de ñocasionalmente góticasò a ñaltamente góticasò (2002, p. xxi), daí os goticismos, quando os traços do Gótico não se fazem verificar integralmente. Dentro de tal perspectiva, sobressai no poema ñA Baronesaò (FERREIRA, 1881, p. 161-162) a encenação da mulher fatal, associada duplamente ao vício e à aristocracia. ${ }^{4}$

\section{A Baronesa}

(1880)

Era rica e formosa a dama melancólica

Viúva de um barão ignóbil e gotoso, Um tipo que morrera um dia de uma cólica

ï Um velho urso manhoso!... ï

Por mero desfastio a moça o desposara, A excêntrica mulher, a impávida leoa... Tinha só um defeito $\ddot{I}$ era trair na cara $\mathrm{O}$ horror que lhe causava esse marido à toa.

Mas fora rico e muito, e tinha umas manias:

\footnotetext{
${ }^{4}$ A ortografia foi atualizada nos poemas de Carlos Ferreira aqui transcritos. 


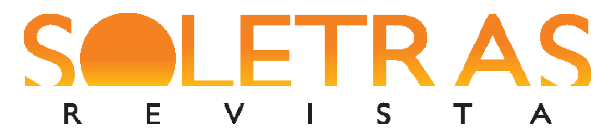

ï Era fazer-se forte e ter uns grandes gestos,

E recitar tremendo as sórdidas poesias

De uns vates desonestos.

Morrera e bem andou... Ela, a mendaz divina, Dama da luva preta e olhos cintilantes,

Tendo sempre a tremer na boca purpurina

Um pedido de amor a dez ou doze amantes,

Aparecia à gente assim com uns leves jeitos

De sol não mencionado em obras de um astrólogo,

Balbuciando a medo uns cálidos conceitos

De incandescente prólogo...

Por vezes ela ouviu de lábios escaldados

Candentes confissões envoltas n'um pedido...

Mas sem nunca esquecer os juramentos dados

Ao lorpa que morrera, ao parvo do marido!

E assim mais de um ilustre e grave personagem

Dandys velhuscos já, acabrunhados tios,

Viram rolar no pó do amor toda a bagagem,

ï Reumáticos vadios!... ï

$* * * * * * * * * * * * * * * * * * * * * * * * * * * * * * * * * * * * * * * * *$

Mas o que faz agora a rica baronesa,

A pálida lutuosa, a dama de espavento?

ï Confessa-se e comunga e faz jejuns, e reza,

$\mathrm{E}$ vive a dar pensões aos frades de um convento!...

Em oito quartetos em metros alexandrinos divididos em hemistíquios perfeitos, com a presença de alguns heroicos quebrados, o poema evidencia o cuidado formal vigente na poesia brasileira do final do século XIX, eclética em sua confluência de estilos, mas firme em seu pendor esteticista. Mesclando um retrato um tanto realista da mulher e seus amantes a clichês românticos da mulher fatal, o texto se coaduna com a postura politizada de Carlos Ferreira, principalmente neste momento da história do país em que os ideais republicanos e abolicionistas estavam na ordem do dia. Neste sentido, e pelo contexto apenas, é que poderíamos vislumbrar na baronesa do poema alguma relação com o Brasil. No entanto, lido sem ter em mente este momento da história brasileira, o poema não apresenta nenhuma marca da cor local, e, assim, as situações apresentadas ï a mulher que se eleva socialmente pelo casamento, a postura deseroicizada do barão, descrito como um tolo destituído de qualquer característica tradicionalmente associada ao mito da nobreza, o retrato desidealizado dos 


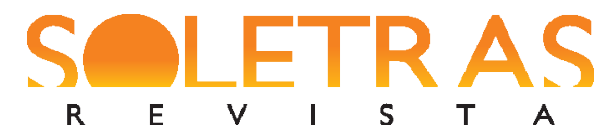

DOSSIÊ ï N. 34 ï 2017.2 ï FERNANDO MONTEIRO DE BARROS MÁRCIO ALESSANDRO DE OLIVEIRA

amantes, a contrição hipócrita da baronesa no final ï poderiam se passar em qualquer cenário do continente europeu naquela época.

Evidentemente, não se trata de um poema gótico à primeira vista. Mas há nele, contudo, de forma sutil, a presença de goticismos. Posto todo o realismo que reduz o barão do poema ao plano do ignóbil, ao avesso do ideal de nobreza, mesmo assim a titularidade é por demais simbólica e significativa no texto, que estabelece o contraponto entre a aristocracia e os ideais democráticos, historicamente incompatíveis (MORGADO, 2008). No Gótico, o aristocrata tradicionalmente encarna a vilania, como o príncipe Manfred de $O$ castelo de Otranto, e, por vezes, até mesmo a monstruosidade, como o conde Drácula. Conforme afirma Fred Botting (2002, p. 285), o estilo gótico encena ños excessos aristocráticosò e confere à aristocracia uma aura ñsombria e ameaçadoraò, no que esta classe social, ñdespojada do poder econômico e políticoò, é imaginada como ña antítese dos valores burgueses de sobriedade, mérito e diligênciaò, em tempos de ñcultura comercial e produção racionalò.

Além do motivo do aristocrata como vilão gótico tradicional, o topos da mulher fatal se insinua no texto, com tintas sinistras. Além de ñformosaò, a baronesa é uma ñdama melancólicaò, uma ñexcêntricaò, uma ñmpávida leoaò, o que faz ecoar a representação do desejo predatório da mulher-vampiro, a um só tempo morta ï ñdama melancólicaòï e voraz ï ñmpávida leoaò. A baronesa do poema se insere na galeria das mulheres traiçoeiras ï ñmendaz divinaò, cuja beleza atrai para destruir, à guisa das sereias da mitologia grega e de várias representações do feminino como monstruosidade sedutora. O verso ñdama da luva preta e olhos cintilantesò ratifica essa associação, a partir de adereços inequivocamente góticos. Destaca-se também a ñoca purpurinaò, alusão não apenas aos lábios do vampiro como também ao culto da mulher maquiada, que reflete, na poesia de Carlos Ferreira, a forte influência de Charles Baudelaire (AMARAL, 1996, p. 39), com todo o seu arsenal de goticismos urbanos.

Os ñdez ou doze amantesò da baronesa do poema também contribuem para inscrevêla no tema da ñainha barregãò, ou ñainha prostitutaò: a meretriz ou cortesã que ascende à nobreza pelas artes de sua volúpia. Tal mote pode ser encontrado na cena de fantasmas do poema narrativo $O$ Conde Lopo, de Álvares de Azevedo (2000, p. 447), essencialmente gótico: 


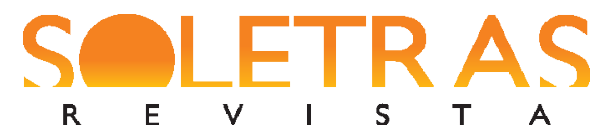

Eu dizia

Que tu ï outrora barregã ï rainha

Caprichosa mulher de ardentes gozos,

Prostituta, sentaras-te num trono;

E davas como leito aos favoritos

Teus tálamos doirados e macios.

A baronesa do poema de Carlos Ferreira, dentro da perspectiva dicotomizante do Romantismo ï que fanopeicamente se perpetua nos poemas finisseculares do poeta gaúcho ï é avatar da mulher-demônio, a despeito da religiosidade de fachada do último quarteto, o que, todavia, remete ao destino final de Manfred, o primeiro vilão gótico, que termina seus dias penitente em um mosteiro. Os goticismos são inegáveis no texto, portanto.

Todavia, para que possamos inscrevê-lo na categoria de Gótico brasileiro, é necessário que se estabeleça o cotejo com o poema ñA Escravaò (FERREIRA, 1881, p. 167168), localizado poucas páginas adiante, no mesmo livro.

\section{A Escrava}

ñMais uns cinquenta açoites! Q̀ brada furioso, altivo

Ao rígido carrasco o bárbaro senhor;

ï ñQue jorre o sangue vivo

E que se estorça e morra em convulsões de dor!

$\tilde{n ̃ E}$ mister ensinar a essa maldita raça

A cumprir seu dever! Puxe-lhe mais! Assim!...

Deixemo-nos de graça,

Um negro é sempre um negro! É quase um bicho, enfim!

ñEssa atrevida ousou, sem me pedir licença,

Inda há pouco chorar!... Pois há de agora rir...

Não creia que é doença

O que ela diz que tem... bem se vê: 'stá a fingir!

ñDê-lhe mais dez e basta, e fica já sabendo

Quem é senhor aqui, e deixe-a aí gritar,

Que eu ainda estou vendo

Ser preciso outra vez a festa começar...ò

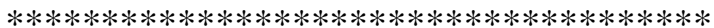

O feitor atirara o grosso relho a um canto,

Findara-se a tarefa, e a vítima a gemer

Foi-se, banhada em pranto,

De rastos, sem alento, e quase que a morrer!... 


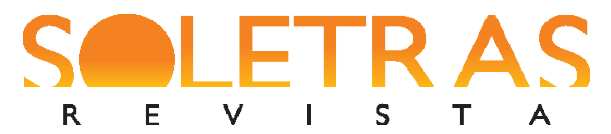

DOSSIÊ ï N. 34 ï 2017.2 İ FERNANDO MONTEIRO DE BARROS MÁRCIO ALESSANDRO DE OLIVEIRA

Pelos rasgões da roupa imunda, esfarrapada

Via-se do azorrague o vestígio cruel,

A carne lacerada

Como Jesus na cruz, ao dar-lhe o algoz o fel.

Praticara um delito enorme a escrava, vê-se!...

De joelhos, chorosa, implorara ao senhor

Ah! que não a vendesse

Sem o seu pobre filho, um nada!... o seu amor!...

Pela estrutura semelhante $\ddot{I}$ aqui sete quartetos alexandrinos, ao invés de oito, também entremeados de heroicos quebrados, mas com a ressalva de que o primeiro verso, bem como o décimo segundo, extrapola as doze sílabas ï e pelo retrato de mulher diametralmente oposto ao do poema anterior, ñA Escravaò estabelece um contraponto com ñA Baronesaò, em que confluem várias antíteses, e, consequentemente, confere ao poema anterior a inserção no campo temático do Gótico brasileiro.

Esta inserção se dá apenas se tomarmos ñA Escravaò como parâmetro. O Gótico brasileiro frequentemente apresenta um pano de fundo ligado ao passado senhorial e escravocrata do Brasil, o que pode ser aferido tanto na obra de Gilberto Freyre (BARROS, 2014) quanto nos romances de Cornélio Penna e Lúcio Cardoso (BARROS, 1998; 2016). Nesse sentido, há uma forte semelhança com o Southern Gothic ï o Gótico sulista norteamericano, que também tem na história da escravidão o seu pano de fundo principal (ELLIS, 2013, p. xx). Desde seu primeiro comparecimento literário no romance de Horace Walpole, o Gótico apresenta como enredo basilar os crimes e pecados da família patriarcal, perpetrados pelo páter-famílias (WILLIAMS, 1995), e, tanto no Southern Gothic quanto no Gótico brasileiro, este muitas vezes assume a forma de impiedoso senhor de escravos, como se pode ver no personagem do Comendador Fernando do romance Úrsula, de Maria Firmina dos Reis, de 1859 (SANTOS, 2017).

Este romance, pioneiro em nossa literatura pela autoria feminina e pela postura abolicionista, pode ser considerado pioneiro também do Gótico brasileiro, uma vez que vários elementos convencionais da estética gótica se fazem presentes na narrativa, em um cenário inequivocamente local. À semelhança do enredo de O castelo de Otranto, temos em Úrsula a figura de um vilão aristocrático cruel que persegue uma donzela indefesa, motivado por uma paixão de teor acentuadamente sexual, além de também marcada pela transgressão do incesto, 


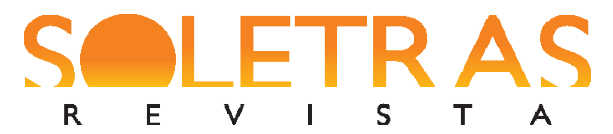

DOSSIÊ ï N. 34 ï 2017.2 Ï FERNANDO MONTEIRO DE BARROS MÁRCIO ALESSANDRO DE OLIVEIRA

sendo que, aqui, o enredo e os personagens da tradição gótica são integrados ao espaço e ao contexto sociocultural do Brasil do século XIX, em pleno período monárquico e escravocrata de nossa história.

É bem pouco provável que Carlos Ferreira tenha tido contato com o romance de Maria Firmina dos Reis, que permaneceu praticamente desconhecido por mais de um século. No entanto, muito provavelmente pela postura abolicionista desses dois autores e pela ostensiva presença de goticismos nas obras de ambos, faz-se tentador estabelecer um paralelo entre alguns personagens de Úrsula e os dois poemas de Carlos Ferreira aqui abordados. A personagem Adelaide, que se casa com o pai de seu noivo e passa a se refestelar no luxo das vestimentas e adereços identificados com o imaginário aristocrático ï ñadornava-a um rico vestido de seda cor de pérolas, e no seio nu ondeava-lhe um precioso colar de brilhantes e pérolas, e os cabelos estavam enastrados de joias de não menor valorò (REIS, 2017, p. 82) ï apresenta retrato muito semelhante ao da baronesa de Carlos Ferreira, igualmente erguida à posição social privilegiada pelo casamento por interesse, com ressonâncias do motivo da ñainha barregãò, e, como a baronesa, retratada em pinceladas góticas como mulher-demônio:

A mulher que tinha ante meus olhos era um fantasma terrível, era um demônio de traições, que na mente abrasada de desesperação ýgurava-se-me sorrindo para mim com insultuoso escárnio. Parecia horrível, desferindo chamas dos olhos, e que me cercava e dava estrepitosas gargalhadas. (REIS, 2017, p. 82)

O senhor sádico e impiedoso do poema de Carlos Ferreira se insere na mesma tipologia do Comendador Fernando P. do romance de Maria Firmina dos Reis, em voltagem gótico-brasileira que se assemelha aos ñcrimes cometidos contra os escravos negros por seus senhores brancosò (MARSHALL, 2013, p. 7) do Gótico sulista norte-americano, conforme a seguinte passagem de Úrsula, narrada pela personagem escravizada Susana:

O comendador P. foi o senhor que me escolheu. Coração de tigre é o seu! Gelei de horror ao aspecto de meus irmãos... os tratos, porque passaram, doeram-me até o fundo do coração. $\mathrm{O}$ comendador $\mathrm{P}$. derramava sem se horrorizar o sangue dos desgraçados negros por uma leve negligência, por uma obrigação mais tibiamente cumprida, por falta de inteligência! E eu sofri com resignação todos os tratos que se dava a meus irmãos, e tão rigorosos como os que eles sentiam. E eu também os sofri, como eles, e muitas vezes com a mais cruel injustiça. (REIS, 2017, p. 103-104) 


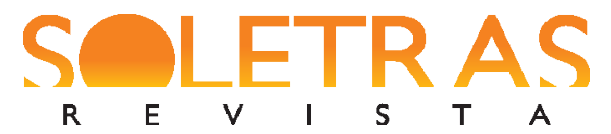

DOSSIÊ ï N. 34 ï 2017.2 ï FERNANDO MONTEIRO DE BARROS MÁRCIO ALESSANDRO DE OLIVEIRA

Além da figura do vilão gótico encarnada localmente no senhor de escravos, o poema de Carlos Ferreira, em postura antitética ao poema da ñBaronesaò, retratada como mulherdemônio e encarnação do vício, apresenta a ñEscravaò como mulher-anjo, encarnação da virtude na figura da mãe, sacralizada no Romantismo, fundida ao topos gótico da ñdonzela em apurosò, vitimada pelo senhor cruel. Nesse ponto também há uma correspondência com a narrativa de Maria Firmina dos Reis, quando o personagem Túlio narra a separação forçada de sua mãe escrava, comprada pelo Comendador Fernando, que de seu filho a apartou (REIS, 2017, p. 137).

É provável que a leitura de romances góticos ingleses tenha contribuído para a formação de Maria Firmina dos Reis, pois, apesar da predominância dos romances franceses na época, é sabido que ñdesde o decênio de 1820 os romances góticos fizeram parte das levas de romances ingleses que começaram a aportar no Rio de Janeiroò (SÁ, 2010, p. 13).Já a poesia de Carlos Ferreira, como anteriormente assinalado, sempre conteve fortes traços de intertextualidade com poetas marcados pela estética gótica. Surpreendentemente, o republicanismo de Ferreira, tão marcante em Redivivas de 1881, dá lugar, em 1908, a um forte saudosismo da monarquia e a uma veemente crítica à República, no poema ñA Catástrofeò, de Plumas ao vento, sobre a queda do Império. No prefácio ao livro de crônicas Feituras e feições, Ferreira já lamentava que a oligarquia, ñuma espécie cavilosa de hereditariedade monárquica que só serve para desabonar os belos princípios da democracia puraò, se fizera perpetuar no novo regime, em evidente traição às promessas de se constituir ño governo do povo pelo povoò (FERREIRA, 1905, p. VII). Mas o olhar do eu lírico, que lamenta a deposição de D. Pedro II Ï por quem, contraditoriamente, como já vimos, o poeta sempre nutrira admiração $\ddot{i}$ traz ressonâncias da postura aristocratizante e antiburguesa dos decadentes franceses, como J.-K. Huysmans (1848-1907), além de denunciar que a República acabou por submeter o povo brasileiro a uma tirania maior, como no trecho abaixo (FERREIRA, 1908, p. 53-63):

Oh! esse ideal sublime

República chamado, alheio a todo o crime, Que só o amor deseja, a segurança, a luz ï Astro que aponta um norte... Deus que a amar induz Esse ideal que condena a vingança, a crueza, Que só quer a igualdade em vez da ñrealezaò, Acaso, oh! grande Deus, é esse o loiro ideal 


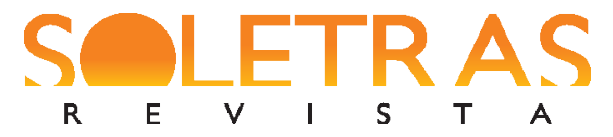

que eu outrora entrevi ï esplêndido fanal?

Acaso é esse o ideal radiante de poesia

Que a juventude sonha, e que eu sonhei um dia,

Louco de entusiasmo?

Amarga decepção!

Triunfa em minha pátria a vil bajulação.

Vitorioso, audaz, ei-lo que aí vai galgando

As grandes posições, o miserável bando

Da ignorância e da infâmia! Ao passo que a honradez

Sucumbe, dos vilões sob os profanos pés...

Gente sem tradição e sem ideal futuro,

Que não sabe o que faz e anda a palpar no escuro.

Vede: - ao clarão do dia a ingratidão venceu!

E o mundo é sempre o mesmo! E é sempre o mesmo céu!

Onde o talento estava, eu vejo a ignorância;

Toma a vez da modéstia a impávida arrogância,

E a covardia indigna insulta, afronta a quem

A audácia de histriões para subir não tem.

A consciência, essa ave imensamente pura,

Espavorida foge, ante a profunda e escura

Noite do apocalipse. Cospe a anarquia fel,

E só se ouve sinistro o atroador tropel

Do rubro despotismo. O povo, humilde, mudo,

Passivamente marcha... E se resigna a tudo

Como a besta ao chicote. É uma alimária vil,

Esse mesmo que foi outrora o Anteu viril

capaz de originar os rígidos tufões,

A tempestade, o raio, e mil revoluções

Vingadoras, fatais! Hoje nem mesmo crê

No divino direito e nem tem Deus nem fé.

Fizeram-no uma cousa, em vez de uma entidade

Sagrada, cuja força é o bem e a liberdade.

De um valente Titã que sempre ousado foi,

Transformaram-no em fraco e paciente boi, que suporta, arquejante, os mais pesado jugos

Lambendo, humilde, a mão de seus cruéis verdugos!

O olhar decepcionado do eu lírico, que vê na consumação republicana brasileira a frustração dos sonhos e ideias da juventude, motivado pelos rumos autoritários e ditatoriais tomados pelo regime republicano, principalmente durante a presidência do marechal Floriano Peixoto (1891-1894), também confere aos versos notas de goticismo, feito em tom exaltado que remete a um condoreirismo às avessas.

Há um outro ponto de contato entre Úrsula e os poemas ñA Baronesaò e ñA Escrava. Além da postura abolicionista e de crítica social seus autores, o romance de Maria Firmina dos Reis ñ coloca o negro como referência moral da narrativaò, como enfatiza Eduardo de 


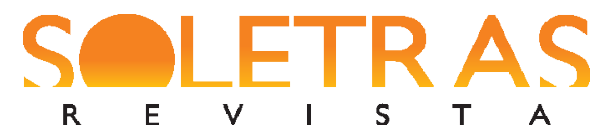

DOSSIÊ ï N. 34 ï 2017.2 İ FERNANDO MONTEIRO DE BARROS MÁRCIO ALESSANDRO DE OLIVEIRA

Assis Duarte (2013, p. 149), pois o personagem Tancredo $\ddot{i}$ o branco sinhozinho $\ddot{i}$ textualmente se dirige ao personagem Túlio ï o negro escravizado ï nos seguintes termos: ñpudera todos os corações assemelharem-se ao teuò e, mais adiante, diz o narrador a respeito do personagem Tancredo: ñé que em seu coração ardiam sentimentos tão nobres e generosos como os que animavam a alma do jovem negroò (REIS, 2017, p. 33-34). No confronto entre os dois poemas de Ferreira, a escrava surge como paradigma da virtude, enquanto a baronesa é apresentada como a encarnação do vício.

\section{Considerações finais}

Para a hipótese deste trabalho $\ddot{i}$ os dois poemas de Carlos Ferreira aqui assinalados como textos fundadores do Gótico brasileiro, tais como Úrsula e ñA Orgia dos Duendesòï o poema da baronesa só pode se inscrever dentro dessa categoria se lido em confronto com o poema da escrava, que, no contexto histórico da época, permite vislumbrar o pano de fundo nacional em meio a um imaginário goticista, em uma espécie de espelhamento invertido. Decerto que, com toda probabilidade, tal viés não deve ter feito parte das cogitações do autor, mas é digno de nota que, na proposição do conceito de Gótico brasileiro, nos poemas abordados o negro também avulte como referência e parâmetro: a baronesa só entra em tal categoria $і ̈$ de texto fundador do Gótico brasileiro ï se iluminada pela escrava.

Apesar de sua obra profícua, que se espraiou pelos três gêneros literários e pelo jornalismo, Carlos Augusto Ferreira permanece um autor praticamente desconhecido. Há sobre ele dois subcapítulos em manuais de história da literatura brasileira: o da coleção organizada por Afrânio Coutinho, escrito por Fausto Cunha (1969, p. 212-213), e o da coleção escrita por Massaud Moisés, que, ao contrário de Cunha, deixa transparecer um olhar menos desaprovador de sua obra, que considera de ñira inspiradaò (MOISÉS, 1984, p. 274). Jamil Almansur Haddad, em texto de 1956, chegou a considerar o poema ñModulaçõesò, do livro Alcíones, de 1872, ña primeira tradução de poema de Baudelaire no Brasilò(HADDAD, 1984, p. 42), equívoco partilhado por Massaud Moisés (1985, p. 14-15) e retificado por Antonio Candido, que reconhece a precedência de Luís Delfino (1834-1910), com sua tradução de ñLe Poisonò, de 1871, como primeiro registro baudelairiano em nossas letras. Da mesma forma, Péricles Eugênio da Silva Ramos (1967, p. 17) e Glória Carneiro do Amaral (1996, p. 37), reconhecem Carlos Ferreira como um dos primeiros poetas brasileiros a apresentar em sua 


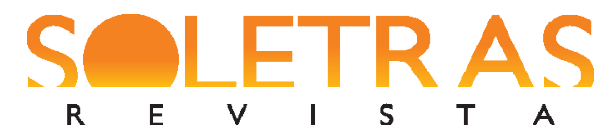

DOSSIÊ ï N. 34 ï 2017.2 İ FERNANDO MONTEIRO DE BARROS MÁRCIO ALESSANDRO DE OLIVEIRA

poesia a influência do vate francês, o que também atesta Fausto Cunha: ñ poeta das Redivivas foi, entretanto, um dos poucos românticos de 1870 que sofreram confessadamente o influxo de Baudelaire, a quem traduziu e imitouò(1969, p. 213).

Antes da publicação de seu primeiro livro de poesia de 1865, Carlos Ferreira havia sido efusivamente saudado por Machado de Assis, em crônica de 29 de novembro de 1864, publicada no Diário do Rio de Janeiro:

Falemos de um poeta nascente. É o Sr. Carlos Augusto Ferreira, do Rio Grande do Sul, jovem de esperançoso talento, que vai publicar brevemente um volume de versos. $O$ Mercantil de Porto Alegre escreve a respeito do jovem poeta algumas linhas que eu transcreveria, se me sobrara espaço. É moço, é órfão, é pobre; a pobreza, a mocidade, a orfandade foram e são outros tantos motivos para as manifestações da sua musa auspiciosa. Animálo é dever. Pode vir a ser uma das glórias do país; não lhe cortemos, com uma desdenhosa indiferença, o ardor da sua vocação, que de tantos obstáculos triunfa. (ASSIS, 1937, p. 74)

Se ao longo de sua vida a exortação de Machado provou-se eficaz, depois de sua morte a produção literária de Carlos Ferreira, que reflete a transição do Romantismo para o Parnasianismo e a transição do Império para a República, pareceu legar à posteridade apenas o poema ño Baile das Múmiasò. De sua biografia, sobrevive ï em raríssimos estudos de literatura brasileira $\ddot{i}$ apenas o reconhecimento de ter sido um de nossos primeiros baudelairianos. Oxalá a leitura de ñA Baronesaò e ñA Escravaò, e suas intersecções com o Gótico brasileiro, permita despertar interesse sobre os demais textos de Carlos Ferreira, que ainda aguardam para serem (re)lidos e (re)descobertos.

\section{Referências}

AMARAL, Glória Carneiro do. Aclimatando Baudelaire. São Paulo: Annablume, 1996.

ASSIS, Machado de. Ao acaso (crônicas da semana). In: Obra Completa. Rio de Janeiro: Edições W. M. Jackson,1937. Disponível em: $<$ http://www.literaturabrasileira.ufsc.br/documentos/?action=download\&id=8252> Acesso em: 30 set. 2017.

AZEVEDO, Álvares. O Conde Lopo. In: Obra completa. Org. Alexei Bueno. Rio de Janeiro: Nova Aguilar, 2000. 


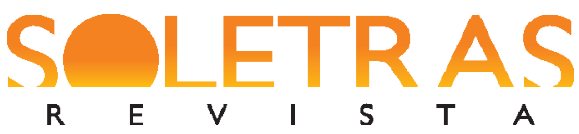

DOSSIÊ ï N. 34 ï 2017.2 İ FERNANDO MONTEIRO DE BARROS MÁRCIO ALESSANDRO DE OLIVEIRA

BARROS, Fernando Monteiro de. A alegoria e o fantasma no Gótico brasileiro: Cornélio Penna e Lúcio Cardoso. Anais do XV Encontro ABRALIC. Rio de Janeiro: UERJ, 2016, p. 2472-2482. Disponível em:

http://www.abralic.org.br/anais/arquivos/2016_1490918496.pdf Acesso em: 10 ago. 2017.

Do castelo à casa-grande: o ñGótico brasileiroœ̀em Gilberto Freyre.Revista Soletras, São Gonçalo, $n^{\circ}$ 27, jan.-jun. 2014. Disponível em:

http://www.e-publicacoes.uerj.br/index.php/soletras/article/view/13050 Acesso em: 19 ago. 2017.

. Vampiros na casa-grande: a brasilidade segundo Lúcio Cardoso. In: SANTOS, Francisco Venceslau (Org.). Produção \& pesquisa em Letras. São Gonçalo, RJ: F. V. dos Santos, 1998.

BOTTING, Fred. After gothic: consumption, machines, and black holes. In: HOGLE, Jerrold E. (Editor). The Cambridge Companion to Gothic Fiction. Cambridge: Cambridge University Press, 2002.

CANDIDO, Antonio. Os primeiros baudelairianos. In: A educação pela noite \& outros ensaios. São Paulo: Ática, 1989.

COLUCCI, Luciana; BARROS, Fernando Monteiro de. Lovecraft e os matizes goticistas em ñThe dreams of the witch-houseò. Revista Abusões, Rio de Janeiro, $\mathrm{n}^{\mathrm{o}}$ 4, jan.-jul. 2017. Disponível em: http://www.e-publicacoes.uerj.br/index.php/abusoes/article/view/27943 Acesso em: 24 ago. 2017.

CUNHA, Fausto. Castro Alves. In: COUTINHO, Afrânio (org.). A literatura no Brasil. Volume II: Romantismo. 2.ed. Rio de Janeiro: Editorial Sul Americana, 1969.

DUARTE, Eduardo de Assis. O negro na literatura brasileira. Revista Navegações. Porto Alegre, v. 6. $\mathrm{n}^{\mathrm{o}}$ 2, jul.-dez. 2013. Disponível em:

http://revistaseletronicas.pucrs.br/ojs/index.php/navegacoes/article/viewFile/16787/10936

Acesso em: 15 ago. 2017.

ELLIS, Jay. On Southern Gothic literature. In: ELLIS, Jay. (Ed.). ELLIS, Jay. (Ed.). Southern Gothic literature (Critical insights). Ipswich, Massachussetts: Salem Press; Amenia, NY: Grey House Publishing, 2013.

EDWARDS, Justin D.; VANCONCELOS, Sandra Guardini. Tropicalizing Gothic. In: Tropical Gothic in literature and culture: the Americas. New York: Routledge, 2016.

FERREIRA, Carlos. Alcyones: poesias. Rio de Janeiro: J.T.P. Soares, 1872.

. Cânticos juvenis. Porto Alegre, Typographia do ñMercantilò, 1865.

Feituras e feições. Campinas: Typ. Livro Azul, 1905. 


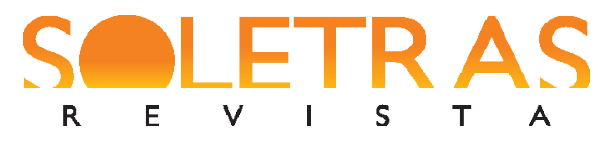

DOSSIÊ ï N. 34 ï 2017.2 Ï FERNANDO MONTEIRO DE BARROS MÁRCIO ALESSANDRO DE OLIVEIRA

. Plumas ao vento. Campinas: Casa Genoud, 1908.

. Redivivas. Typ. da Gazeta de Campinas, 1881.

Rosas loucas:poesias. São Paulo: Typographia do Correio Paulistano, 1871.

FRANÇA, Júlio. O sequestro do Gótico no Brasil. In: COLUCCI, Luciana;

As nuances do Gótico: do setecentos à atualidade. Rio de Janeiro: Bonecker, 2017.

(Orgs.).

HADDAD, Jamil Almansur. Baudelaire e o Brasil (prefácio). In: BAUDELAIRE, Charles. As flores do mal. Trad. Jamil Almansur Haddad. São Paulo: Abril Cultural, 1984.

HOGLE, Jerrold E. (Editor). The Cambridge Companion to Gothic Fiction. Cambridge: Cambridge University Press, 2002.

IANNONE, Carlos Alberto. A vida de Carlos Augusto Ferreira/A obra de Carlos Augusto Ferreira. In: FERREIRA, Carlos Augusto. Histórias cambiantes. Rio de Janeiro: Editora Três, 1974.

MARSHALL, B. M. Defining Southern Gothic. In ELLIS, Jay. (Ed.). Southern Gothic literature (Critical insights). Ipswich, Massachussetts: Salem Press; Amenia, NY: Grey House Publishing, 2013.

MOISÉS, Massaud. História da literatura brasileira: Romantismo. São Paulo: Cultrix, 1984. História da literatura brasileira: Simbolismo. São Paulo: Cultrix, 1985.

MORGADO, Miguel. A aristocracia e os seus críticos. Lisboa: Edições 70, 2008.

RAMOS, Péricles Eugênio da Silva. Poesia parnasiana: antologia. São Paulo: Melhoramentos, 1967.

REIS, Maria Firmina dos. Úrsula. Romance. 6.ed. Belo Horizonte: PUC Minas, 2017.

RIBEIRO, Júlio. Prefácio. In: FERREIRA, Carlos. Redivivas: poesias. Campinas: Typ. Da ñGazeta de Campinasò, 1881.

SÁ, Daniel Serravalle de. Gótico tropical: o sublime e o demoníaco em O Guarani. Salvador: EDUFBA, 2010.

SANTOS, Ana Paula A. dos. Úrsula e a vertente do Gótico feminino no Brasil. In: Revista Mulheres e Literatura. Rio de Janeiro, v. 19, p. s/p, 2017. Disponível em:

http://litcult.net/ursula-e-a-vertente-do-gotico-feminino-no-brasil-ana-paula-a-dos-santos/

Acesso em: 25 ago. 2017.

SANTOS, F. Quirino dos. Prefácio. In: FERREIRA, Carlos. Redivivas: poesias. Campinas: Typ. Da ñGazeta de Campinasò, 1881. 
SPALDING, Walter. Itinerário da literatura sul-riograndense. In: BECKER, Klaus (org.). Enciclopédia Riograndense. $2^{\circ}$ Volume: O Rio Grande antigo. Canoas, RS: Editora Regional, 1956.

VASCONCELOS, S. G. T. - A Formação do Romance Brasileiro: 1808-1860 (vertentes inglesas). Campinas: Unicamp, 2002. Disponível em:

http://www.unicamp.br/iel/memoria/Ensaios/Sandra/sandra.htmAcesso em: 20 ago. 2017.

WILLIAMS, Anne. Art of darkness: a poetics of Gothic. Chicago: The University of Chicago Press, 1995.

\title{
Brazilian Gothic in Carlos Ferreiraô poetry
}

\begin{abstract}
Brazilian poet Carlos Ferreira (1844-1913) presents in his poetry occasional traces of 18th century English Gothic literature. His poems ñA Baronesaò (ñThe Baronessò) and ñA Escravaò (ñThe Slave Womanò), published in his 1881 book Redivivas, stand as primary pieces of what we might call Brazilian Gothic, rather than just being an example of the Gothic presence in Brazilian literature. Following the concept of cultural cannibalism/anthropophagy, Brazilian Gothic implies the presence of Gothic literary conventions in the local landscape of Brazil. The strong intertextuality between Ferreiraôs poems and Maria Firmina dos Reisôs novel Úrsula (1859), another piece of Brazilian Gothic, reinforces this thesis.
\end{abstract}

Key words: Brazilian Gothic. Fin-de-siècle poetry. Intertextuality

Recebido em: 28 de setembro de 2017.

Aprovado em: 10 de outubro de 2017. 